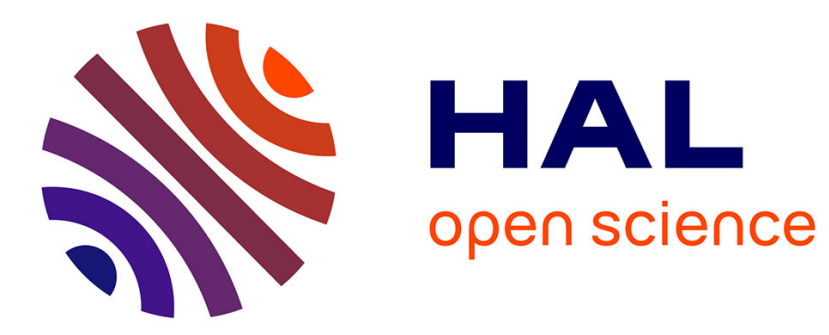

\title{
COMPARATIVE STUDY OF OXYHEMOGLOBIN RADIOLYSIS AND THERMOLYSIS BY MÖSSBAUER SPECTROSCOPY
}

\author{
C. Kellershohn, J. Rimbert, A. Chevalier, Cédric Hubert
}

\section{- To cite this version:}

C. Kellershohn, J. Rimbert, A. Chevalier, Cédric Hubert. COMPARATIVE STUDY OF OXYHEMOGLOBIN RADIOLYSIS AND THERMOLYSIS BY MÖSSBAUER SPECTROSCOPY. Journal de Physique Colloques, 1976, 37 (C6), pp.C6-185-C6-189. 10.1051/jphyscol:1976639 . jpa-00216749

HAL Id: jpa-00216749

https://hal.science/jpa-00216749

Submitted on 1 Jan 1976

HAL is a multi-disciplinary open access archive for the deposit and dissemination of scientific research documents, whether they are published or not. The documents may come from teaching and research institutions in France or abroad, or from public or private research centers.
L'archive ouverte pluridisciplinaire HAL, est destinée au dépôt et à la diffusion de documents scientifiques de niveau recherche, publiés ou non, émanant des établissements d'enseignement et de recherche français ou étrangers, des laboratoires publics ou privés. 


\title{
COMPARATIVE STUDY OF OXYHEMOGLOBIN RADIOLYSIS AND THERMOLYSIS BY MÖSSBAUER SPECTROSCOPY
}

\author{
C. KELLERSHOHN, J. N. RIMBERT, A. CHEVALIER and C. HUBERT \\ Laboratoire de Biophysique, Faculté de Médecine Necker-Enfants Malades, Paris, France

\begin{abstract}
Résumé. - L'étude des modifications en fonction de la dose du spectre Mössbauer de globules rouges artériels irradiés aux rayons $\mathrm{X}$ montre que l'irradiation de l'oxyhémoglobine globulaire entraîne la production d'une forme déoxy ligand free probablement quickly reacting comme dans le cas, bien connu, de la photodissociation ainsi que d'une hémoglobine ferrique high spin. Pour des doses de radiation croissantes, l'hème de ces radioproduits est détruit et un composé final du type ferrique high spin à environnement rhomboédrique est produit. Ces résultats sont obtenus par comparaison avec les spectres RPE.

La spectrométrie Mössbauer montre que les mêmes composés sont produits sous l'action de la chaleur, à l'exlcusion de la forme déoxy ligand free.
\end{abstract}

Abstract. - The study of variations in the Mössbauer spectrum of X-irradiated arterial red cells as a function of dose shows that irradiation of red cells oxyhemoglobin leads to the production of a ligand free deoxy form, probably fast-reacting as in the well-known case of photodissociation, and of a high spin ferric hemoglobin. For increasing radiation doses the heme of these radioproducts is destroyed and a final compound of the type high spin ferric in rhombic environment is produced. These results are obtained by comparison with EPR spectra.

Mössbauer spectrometry shows that these same compounds, excluding the «ligand free » deoxy form, are formed by the action of heat.

1. Introduction. - Although Fricke and Peterson [1] pointed out as early as 1927 that oxyhemoglobin in dilute aqueous solution is oxidized to methemoglobin under X-irradiation, relatively little research has been devoted to the action of ionizing radiations on hemoglobin and its derivatives. In most cases the physical method of observation was optical, which can be troublesome considering the coagulation effects due to possible denaturation of hemoglobin at high radiation doses. The denaturation of hemoglobin and its derivatives by the action of heat or chemical agents has been studied many times $[2,3,4,5]$ usually by electron paramagnetic resonance (EPR) which has the advantage that ferric derivatives of hemoglobin can be observed by this method however opaque the sample. Although less sensitive, the Mössbauer effect offers not only this same possibility, but also that of observing the presence of low-spin ferrous derivatives of hemoglobin such as oxyhemoglobin itself. It therefore seemed interesting to study the changes in the Mössbauer spectrum of arterial red corpuscle samples exposed to different X-ray doses and to heat, then to compare the results obtained with those given by EPR.

2. Materials and methods. $-10 \mathrm{ml}$ blood samples taken from the left ventricle of subjects under exploratory catheterism are centrifuged at 3500 r.p.m. for $5 \mathrm{~min}$. The red cells taken from the sediment are placed in a copper cylinder of height $1 \mathrm{~cm}$ and diameter $1.6 \mathrm{~cm}$, closed at each end by a mylar window. This cylinder is mounted at the end of the cold finger of a liquid nitrogen cryostat in a vacuum chamber closed by two $1 \mathrm{~mm}$ thick beryllium windows perpendicular to the cylinder axis. The result is a $1 \mathrm{~cm}$ thick red cell absorber corresponding to about $1 \mathrm{mg} / \mathrm{cm}^{2}$ of $\mathrm{Fe}$. The cells are irradiated in air at room temperature by a tungsten anode, constant voltage Baltographe CE $50 / 15 \mathrm{X}$-ray tube working under $50 \mathrm{kV}$ and $15 \mathrm{~mA}$. The radiation intensity emitted is $79.4 \times 10^{8}$ ergs. $\operatorname{ster}^{-1} \mathrm{~h}^{-1}$. The axis of the above cylindrical cell container is centred on the X-ray beam axis with its centre $4.5 \mathrm{~cm}$ away form the focus of the tube. Under these conditions the dose rate on the sample is $0.6 \mathrm{Me}-$ garad per hour. Ten irradiation times were used : 0.5 , $1,2,3,4,6,8,10,12$ and 21 hours, corresponding to $0.3,0.6,1.2,1.8,2.4,3.6,4.8,6,7.2$ and 12.6 Megarads doses respectively.

For the heat effect study the red cells are placed in a test tube immersed for 1 to $5 \mathrm{~min}$. in a water bath at a. constant temperature of $80^{\circ} \mathrm{C}$.

The Mössbauer spectra are obtained with a Thenard

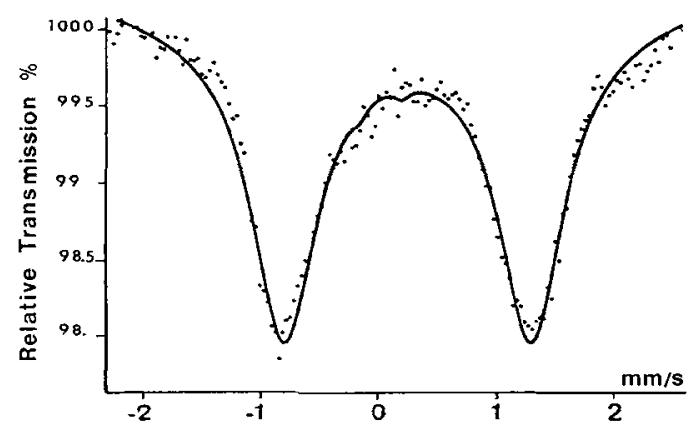

FIG. 1. - Mössbauer spectrum of non-irradiated arterial red blood cells. 
and Victor constant-acceleration instrument [6] combined with an Elscint fast counting scintillation detector and an Intertechnique SA40 400-channel analyser. The red cell absorber at liquid nitrogen temperature is placed at an equal $6 \mathrm{~cm}$ distance from the scintillation counter window and the average position of a $20 \mathrm{mCi}$ ${ }^{57} \mathrm{Co}$-palladium source at room temperature. The spectra are recorded for three days, which represents

DOSE

DOSE

M rads

Mrads
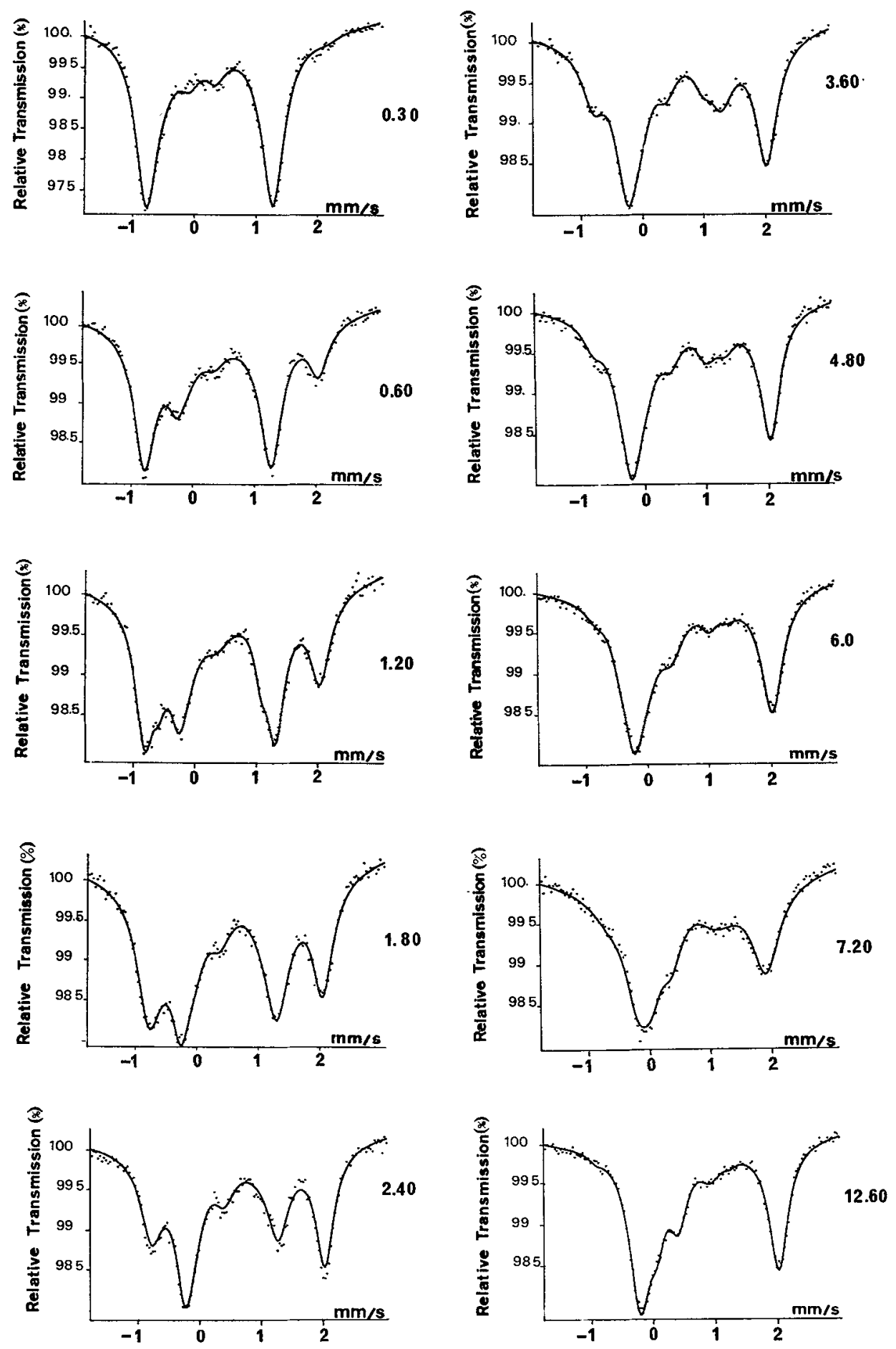

Frg. 2. - Change in the Mössbauer spectrum of arterial red cells as a function of radiation dose. 
7 to 8 million counts per channel. They are analysed by a method of least squares in Lorentzian curves by means of a computer programme giving the width, amplitude and area of these curves. The maximum amplitude is about $1.6 \%$. The isomeric shift is expressed in relation to natural $\mathrm{Fe}$.

3. Results. - Figure 1 shows the Mössbauer spectrum of a red blood cell sample before irradiation; this is a characteristic oxyhemoglobin spectrum with a chemical shift $\delta=0.2 \pm 0.03 \mathrm{~mm} / \mathrm{s}$ and quadrupole splitting $A=2.05 \pm 0.05 \mathrm{~mm} / \mathrm{s}$.

Figure 2 shows the development of the spectrum as a function of radiation dose. As this dose increases three doublets appear beside the initial oxyhemoglobin, one of which, of parameters $\delta=0.89 \pm 0.03 \mathrm{~mm} / \mathrm{s}$ and $\Delta=2.2 \pm 0.1 \mathrm{~mm} / \mathrm{s}$, corresponds within the limits of our measurement precision to the wellknown spectrum of deoxyhemoglobin. The others represent two compounds which we shall call $A$ and $B$, their Mössbauer parameters being

$$
\delta=0.22 \pm 0.02 \mathrm{~mm} / \mathrm{s}
$$

and $\Delta=0.39 \pm 0.02 \mathrm{~mm} / \mathrm{s}$ in the former case and $\delta=0.30 \pm 0.1 \mathrm{~mm} / \mathrm{s}$ and $\Delta=1.41 \pm 0.01 \mathrm{~mm} / \mathrm{s}$ in the latter.

These different components, obtained by computer fitting, are given on figure 3 which is an enlargement

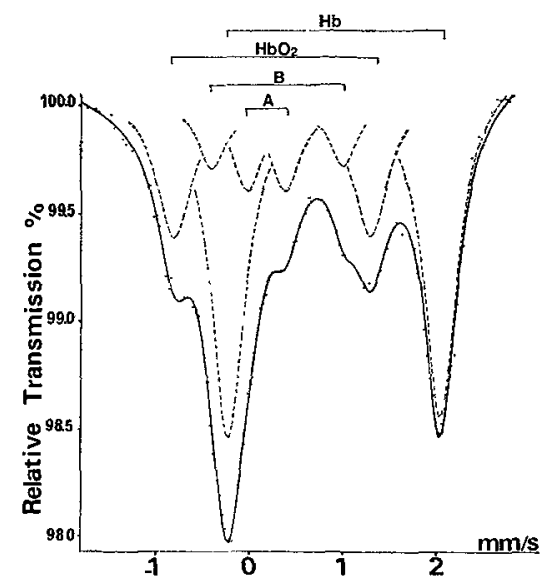

FIG. 3. - Components of the Mössbauer spectrum of arterial red cells irradiated at $3.6 \mathrm{Megarads}: \mathrm{HbO}_{2}$ : oxyhemoglobin; $\mathrm{H}_{\mathrm{b}}$ : ligand free deoxy form; $\mathrm{A}$ : high spin ferric compound in rhombic environment; $\mathrm{B}:$ high spin ferric heme.

of the spectrum relative to the sample irradiated at 3.60 Megarads on figure 2. The oxyhemoglobin spectrum gradually diminishes as the dose rises and disappears completely at about 12 Megarads. At such a dose the spectrum of compound $\mathbf{B}$ has also practically disappeared and the spectrum obtained at 12.60 Megarads, shown on figure 2, consists essentially of the superimposed spectra of deoxyhemoglobin and compound A.
Furthermore in an earlier preliminary study [7] we observed that the irradiation of red cells made up exclusively of deoxyhemoglobin had the appearance of compound $A$ alone and that for very high doses, around 100 Megarads, the deoxyhemoglobin spectrum disappeared completely leaving only the spectrum of compound $\mathrm{A}$, shown on figure 4 as obtained after a 112-Megarads irradiation.

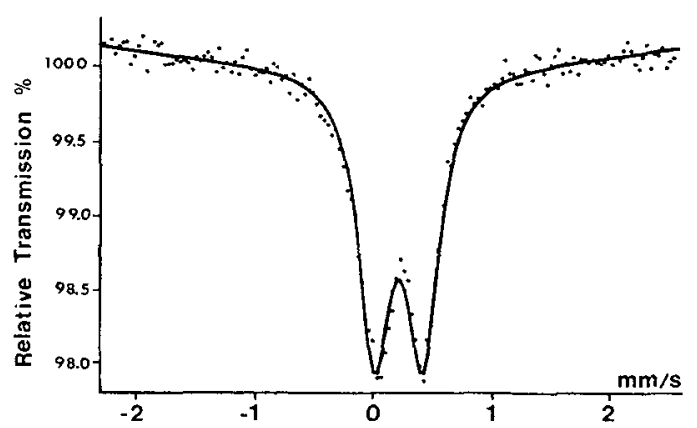

FIG. 4. - Mössbauer spectrum of the high spin ferric compound in rhombic environment produced by 112 Megarads irradiation of arterial red cells.

Figure 5 represents the Mössbauer spectrum of an arterial red cell sample after heating for $1 \mathrm{~min}$. at $80^{\circ} \mathrm{C}$. Heat is seen to act in the same way as X-rays to form compounds $\mathrm{A}$ and $\mathrm{B}$, but the deoxyhemoglobin spectrum is absent.

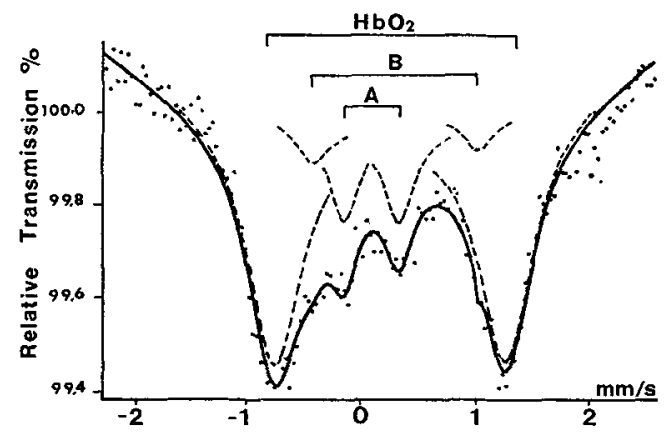

FIG. 5, - Mössbauer spectrum of arterial red cells heated for 1 min. at $80^{\circ} \mathrm{C}$.

Figures $6 a, b$ show the EPR spectra of samples exposed to doses of 112 and 3.60 Megarads respectively, the corresponding Mössbauer spectra appearing on figures 4 and 3. Figure $6 c$ show the EPR spectrum of sample heated at $80^{\circ} \mathrm{C}$ during $1 \mathrm{~min}$.

The spectrum of figure $6 a$ displays an intense line at $g=4.3$, characteristic of a high-spin ferric iron atom in rhombic environment, and a much weaker line at $g=6$ corresponding with equal certainty to a high spin ferric heme (8). At $g=2$ appears a strong line accompanied by satellite lines typical of a copper salt, due in our opinion to contamination of the sample from the copper cylinder in which the cells are heavily irradiated. The spectrum of figure $6 b$ gives the lines at $g=4.3$ and $g=6$, the latter being much more 

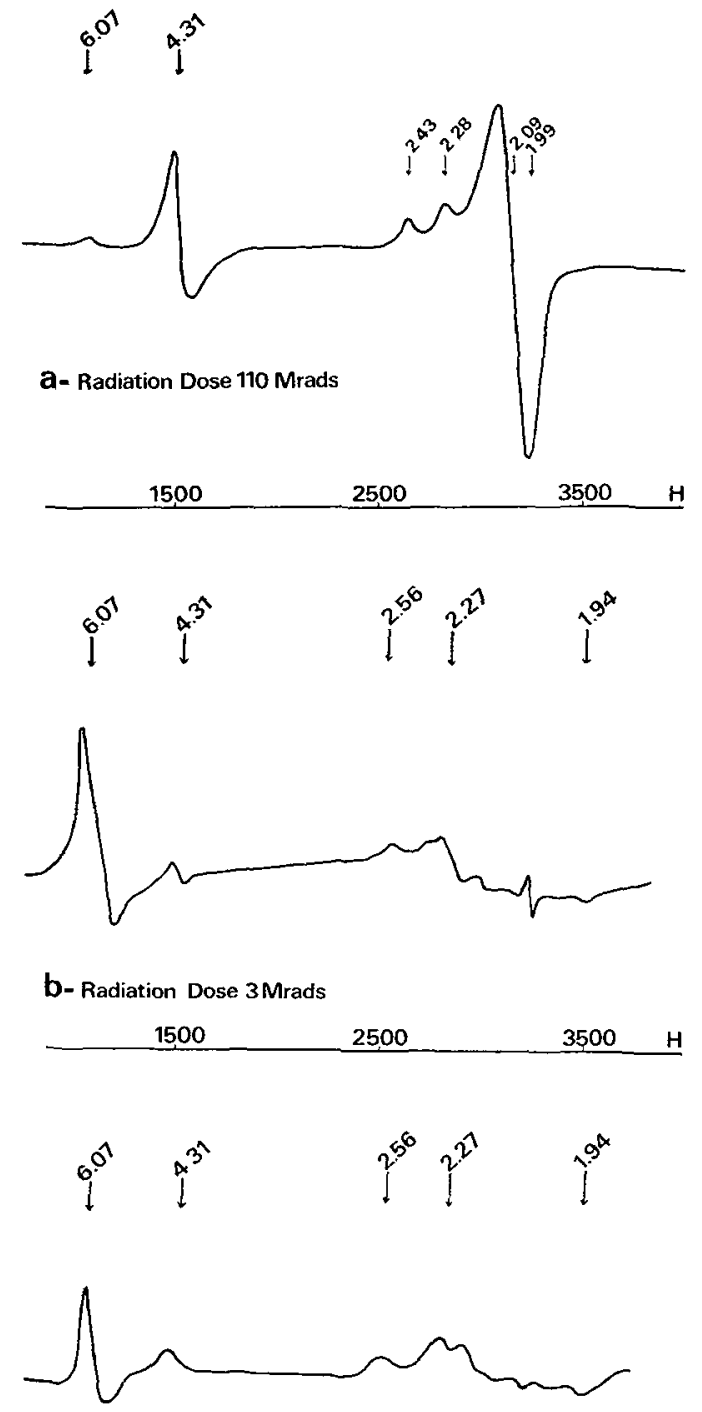

C-Thermolysis $80^{\circ} \mathrm{C}$ during $1 \mathrm{mn}$

\begin{tabular}{rrr}
$1500 \quad 3500 \quad 3500 \quad H$ \\
\hline
\end{tabular}

Fig. 6. - a) EPR spectrum of arterial red cells irradiated at 112 Megarads ; b) EPR spectrum of arterial red cells irradiated at 3.6 Megarads ; c) EPR spectrum of arterial red cells heated 1 min. at $80^{\circ} \mathrm{C}$.

intense compared with the former than in the case of figure $6 a$. On the other hand this spectrum also presents three lines at $g=2.56,2.27$ and 1.94, characteristic of a low spin ferric heme which can represent a $\mathrm{Fe}$ (III) hemoglobin with one $\mathrm{OH}$ in the 6th ligand position, whilst the $g=6$ line would correspond to a Fe(III) hemoglobin with a water molecule in the 6th ligand position (acid methemoglobin). We find again on the spectrum of figure $6 c$ the same lines than on the one of figure $6 b$.

4. Discussion. - The first outcome of the results obtained (Fig. 2 and 3 ) is that X-irradiation of oxyhemoglobin leads to production of the ligand free deoxy form, an effect comparable to the well-known phenomenon of oxyhemoglobin photodissociation. Spartalian et al. [9] showed recently, by Mössbauer spectrometry and low temperature oxyhemoglobin dissociation, that the photoproduct resembles ordinary deoxyhemoglobin in that it is a high spin ferrous complex but differs from this latter in a few slight details. It is possible that the same applies to the oxyhemoglobin X-irradiation product which we have classified as deoxyhemoglobin on the basis of its Mössbauer parameters. This seems to be borne out by the following: the radiodissociation product of oxyhemoglobin itself gives compound $\mathrm{A}$ under $\mathrm{X}$ irradiation. The corresponding dissociation constantis about 3 times as high as that involved in compound A production from the irradiation of ordinary deoxyhemoglobin.

Comparison of the EPR and Mössbauer spectra of the sample irradiated at 112 Megarads (Fig. 4 and $6 a$ ) show that compound $\mathrm{A}$ is distinguished in EPR by a strong line of $g=4.3$. It is therefore a high spin ferric compound in rhombic environment, resulting from destruction of the heme by radiation. Such a structure is found in many organic combinations of iron such as ferrichrome A, transferrin, rubredoxin, iron chelates [10] and is quite consistent with the Mössbauer parameters of compound A. It is interesting to note that several authors $[3,4,5]$, studying the action of heat or various chemicals on oxyhemoglobin by EPR, dwell at length on high spin ferric heme compounds of $g=6$ and low spin ferric compounds in the region of $g=2$ but hardly mention the non-heme rhombic site ferric compounds revealed by the characteristic line at $g=4.3$ on most of their spectra.

Comparison of the EPR and Mössbauer spectra of the sample irradiated at 3.6 Megarads seems to show that compound B corresponds to $g=6$, i. e. a high spin ferric heme, which is not perfectly consistent with the Mössbauer parameters of compound B. It is universally agreed that irradiation of oxyhemoglobin is accompanied by the formation of methemoglobin, i. e. a high spin ferric heme, but the fact remains that compound B does not present the Mössbauer parameters of methemoglobin proper as given by certain authors [11].

Examination of figures 3 and 5 shows that denaturation of oxyhemoglobin by heat is also accompanied by formation of compounds A and B and emphasizes the relationship, often observed for many kinds of substances, between radiolysis and thermolysis which usually cause similar effects. In the present case however two important differences should be noted with regard to the action of these two physical agents. In the first place heat does not dissociate oxyhemoglobin to produce the deoxy form, this effect being apparently specific to radiation. Secondly whereas it is possible, regarding the Mössbauer effect, to isolate component A by irradiation at high enough doses this cannot be 
achieved by heating the sample for longer or shorter periods. When the heating time is increased a spectrum such as that of figure 5 quickly splits by reduction of the pourcentage of Mössbauer effect.

To conclude, the following remark is called for: while all authors agree on the formation of high spin ferric heme compounds, usually referred to as methemoglobin, during irradiation or by the action of heat or chemicals on oxyhemoglobin, opinion is divided where the formation of low spin heme compounds is concerned. It seems that heat and chemicals lead with time, and according to the nature of the latter substances, to the appearance of low spin ferric heme forms known collectively as hemichromes $[3,4]$ as it is shown on figure $6 c$. Some authors however believe in the production of hemochromogens, i. e. low spin ferrous heme compounds [12]. Recently SzwedaLewandowska et al. [13] observed hemochromogen formation during gamma irradiation of oxyhemoglobin at doses around 5 Megarads. The remarkable fact is that by Mössbauer spectrometry we found no evidence, during X-irradiation or heating of oxyhemoglobin, of any compound of the hemichrome type, which should nevertheless be perfectly detectable by this method [14].

Acknowledgement. - We thank Mr. Henry of the Institut de Biologie Physico-Chimique, Paris, for his invaluable assistance in performing EPR Spectra. This work was partly supported by the Fondation pour la Recherche Médicale Française.

\section{References}

[1] Fricke, H. and Peterson, B. W., Am. J. Roentgenol. Radium Therapy 17 (1927) 611.

[2] Hollocher, T. C., J. Biol. Chem. 241 (1966) 1958.

[3] Rachmilewitz, E. A. et al., J. Biol. Chem. 246 (1971) 3356.

[4] Peisach, J. and Blumberg, W. E., Genetical, Functional and Physical Siudies of Hemoglobin, edited by T. Arends, G. Bemski and R. L. Nagel (S. Karger, Basel) 1971, p. 199.

[5] Bemski, G., Biochem. Biophys. Res. Commun. 67 (1975) 1444.

[6] Thenard, J. and Victor, G., Nucl. Instrum. and Meth. 93 (1971) 311.

[7] KellershoHN, C. et al., 5th International Biophysics Congress, Copenhagen, 4th-9th August 1975, I. U. P. A. B., Abstract P-629.
[8] Peisach, J. and Blumberg, W. E., Electron Spin Resonance of Metal Complexes (Plenum Press, New York) 1969, p. 71 .

[9] Spartaltan, K. et al., Biochem. Biophys. Acta 428 (1976) 281.

[10] LANG, G. et al., J. Chem. Phys. 55 (1971) 4539.

[11] Lang, G. and Marshall, Proc. Phys. Soc. 87 (1966) 3.

[12] JonXIs, J. H. P. and Visser, H. K. A., A. M. A. J. Dis. Child. (1956) 588.

[13] SzWEdA-LewandowsKa, Z. et al., Rad. Res. 65 (1976) 50.

[14] Straub, D. K. and Connor, W. M., Ann. N. Y. Acad. Sci. 206 (1973) 383. 